\title{
Alternative Approaches to Financial Crises in Emerging Markets
}

\author{
Jeffrey D. Sachs
}

\begin{abstract}
Developing countries fall into international financial crises for a variety of reasons, including fiscal profligacy, exchange rate mismanagement, international financial shocks, financial liberalization, and weaknesses in the domestic banking sector. Market expectations may play an independent role in a financial crisis, by triggering a self-fulfilling financial panic. International public policy should be aimed first and foremost at avoiding financial crises, but must also be prepared to ameliorate financial crises after they begin.

Despite ample experience with financial crises in the past decade, there are still serious differences of opinion with regard to best means of their avoidance, and their proper management once they occur. These difference relate to the appropriate roles of exchange rate policy, banking policy, fiscal policy, and the international institutions. The purpose of this paper is to review the lessons of the past decade, in order to draw some policy conclusions for developing country governments and for international institutions such as the IMF, World Bank, and the Bank for International settlements.
\end{abstract}

Jeffrey D. Sachs is Director of the Harvard Institute for International Development (HIID) and Galen L. Stone Professor of International Trade, Harvard University. The paper was prepared at background for discussion during meetings in Basel, SZ, December 9-10, 1995. 


\title{
Alternative Approaches to Financial Crises in Emerging Markets
}

\author{
Jeffrey D. Sachs
}

\section{Avoiding international financial crises}

At the risk of gross analytical oversimplification (and in lieu of formal models), I will focus on three main types of international financial crises that plague emerging market economies:

(1) fiscal crises: the Government abruptly loses the ability to role over foreign debts and to attract new foreign loans, possibly forcing the government into rescheduling or default of its obligations;

(2) exchange crises: market participants abruptly shift their demands from domestic-currency assets to foreign-currency assets, depleting the foreign exchange reserves of the central bank in the context of a pegged exchange rate system;

(3) banking crises: commercial banks abruptly lose the ability to role over market instruments (CDS) or to meet a sudden withdrawal of funds from sight deposits, thereby throwing the banks into illiquidity and possibly insolvency.

While these three types of crises are logically distinct, and in some cases come in a "pure" form, they often arrive in combination, since common underlying shocks or market expectations are likely to operate simultaneously in the market for government bonds, the foreign exchange market, and the market for bank assets.

For each type of financial crisis, we can find cases of four distinct triggering mechanisms. The first is an exogenous shock to markets that causes market agents to reassess the ability of the government, the central bank, or the commercial banks, to meet various intertemporal commitments. For example, the collapse of the term of trade of an oil-rich country may call into question the debt-servicing capacity of the government, thereby reducing its creditworthiness. Or a terms-of-trade collapse might lower domestic prices, in turn undermining the solvency of the banking system, and thereby provoking a banking crisis. Frequently, a rise in world interest rates undermines the ability of the government or the banks to obtain further loans.

The second possible cause of financial crisis is an inadvertent policy shock, in which a policy reform in one market 
triggers an adverse market reaction in another part of the economy. For example, money market liberalization might cause a rise of money market interest rates which in turn leads to disintermediation of the commercial banks, and to a banking crisis. Alternatively, if the government was borrowing at low domestic interest rates, internationalization of financial markets might cause a hardening of terms for government borrowing, leading to a fiscal crisis.

The third possible cause of crisis is the exhaustion of borrowing limits, whether by the government, the central bank, or the commercial banks. All market borrowers have borrowing limits determined by their intertemporal solvency and institutional constraints (e.g. prudential limits on borrowing that govern the borrowers and the creditors). In some cases, these limits produce "boom-bust" cycles, in which the borrower incurs debts very quickly up to the borrowing limit, and then suddenly is unable to borrow further beyond that point. This may lead to a crisis of the borrower itself (if the arrival at the borrowing limit is not properly anticipated), or to a crisis among other borrowers in the economy, if the sudden cutoff of funding leads to a sharp shift in market conditions.

Suppose, for example, that after the end of capital controls, a country's commercial banks borrow very heavily in international capital markets, until their borrowing limit is reached. Initially the borrowing will lead to a boom in domestic spending, as the banks intermediate a large flow of foreign loans. This initial boom will also tend to produce a real exchange rate appreciation. Once the banks are fully borrowed up, the inflows stop; the domestic credit markets tighten; domestic demand declines; and their is almost surely the need for an exchange rate depreciation, to reverse the preceding appreciation. This kind of boom-bust cycle in bank borrowing abroad contributed to the onset of financial crises in Argentina and Mexico in the past year.

The fourth possible cause of crisis is a self-fulfilling panic. In almost all financial markets, asset prices may be subject to multiple "rational" equilibria, including highly adverse equilibria such as government bond crises, foreign exchange crises, or banking crises. These types of panics are well known and have been discussed and debated for nearly two centuries, even if there remain important differences of opinion about the likelihood and frequency of self-fulfilling panics. Consider three cases of panic, one for each of our paradigmatic financial crises.

A self-fulfilling fiscal crisis emerges when the markets "rationally" expect the default of an illiquid, but solvent, government borrower (see Sachs, 1984, and Sachs, Tornell and 
Velasco, 1994). Suppose that the government has a solvency limit of $\$ 100$ billion (equal to the discounted value of future taxation that can be devoted to debt servicing), and a current debt of $\$ 50$ billion in short-term liabilities. Suppose also that the maximum debt-servicing capacity in any one year is far below \$50 billion. Individual creditors will be happy to roll over their claims on the government, and even to increase their exposure, if they are confident that other creditors will continue to lend. If a panic begins, however, in which each creditor believes that the other creditors will withdraw their short-term claims, then the individual creditor will also call in his claims. The government will find itself unable to borrow, and may be pushed into default since it is unable to come up with $\$ 50$ billion in short-term revenues.

A self-fulfilling foreign exchange crisis can similarly arise (see Obstfeld, 1995). Suppose that the government is defending a mildly overvalued exchange rate, trading off higher unemployment for lower inflation in the short term. An exchange rate attack begins, in which market participants believe that the Central Bank will choose to devalue in order to reduce short-term unemployment. In order to defend the exchange rate, the Central Bank would have to raise interest rates sharply, which would do grave damage to the banking system and the real economy. Therefore, the Central Bank decides to forego a defense of the currency, and resets the rate at a more competitive level in line with the sudden shift in market expectations. In this way, there may be two rational market expectations: no devaluation (and no panic), or panic followed by devaluation.

A self-fulfilling banking panic is the most familiar of these cases (see Dybvig and Diamond, 1983). A bank's business is to engage in maturity transformation, taking short-term liabilities and long-term assets. This maturity transformation exposes banks to the possibility of a bank run. Individual depositors begin a panicked withdrawal of funds on the belief that other depositors are also withdrawing their funds. Each depositor knows that the bank lacks the funds in the short-run to meet all demands for withdrawals. In this way, an otherwise solvent bank can be pushed into insolvency.

Based on theory and recent experience, can we draw certain policy prescriptions about how to avoid financial crises, other than the obvious ones of fiscal discipline, realistic exchange rate policy, banking supervision, and the like? I think the answer is yes, with the proviso that a full treatment of the issues here requires a vastly more detailed analysis and argumentation. There are, nonetheless, several general lessons that can be gleaned from recent cases. 


\section{Strictly pegged exchange rates raise the risks of financial crises, and therefore should be used only in very specific circumstances.}

Consider the various sources of financial crises. Adverse external shocks, e.g. a fall in the terms of trade, a rise in world interest rates, a shift in world demand against a country's exports, tend to require a real depreciation that is extremely difficult to achieve through internal deflation (as opposed to currency depreciation). Similarly, the exhaustion of external borrowing limits (e.g. when a government has accumulated a heavy load of foreign debt) typically requires the shift from current account deficit to current account surplus, which in turn requires a real exchange rate depreciation.

Markets know that pegged exchange regimes are fragile in the face of adverse external shocks. Market participants are thus are likely to speculate against pegged rates in the face of such shocks. Either the defense of the pegged rate will prove very costly in the face of such speculation (as in Argentina in 1995), or more likely, the market pressures will lead to the abandonment of the pegged rate (as in several ERM countries in 1992, or Mexico in 1994). See Obstfeld and Rogoff, 1995, for similar conclusions.

Perhaps less obviously, self-fulfilling panics are also much easier to handle, or can be obviated entirely, by floating exchange rate regimes compared with pegged rate regimes. Consider the case in which the government owes debts of 50 billion in local currency (e.g. pesos), with a solvency limit of 100 billion pesos. We noted earlier that a self-fulfilling panic can ensue, even though the government is not at its solvency limit, if each creditor believes that other creditors will stop lending, thereby pushing the government into default. In a floating exchange rate regime, the Central Bank can stop the panic by standing behind the government, promising to offer credits to the government so that the government can avoid default on its market debts. The market knowledge that the Central Bank stands ready to provide credit to the government to prevent a default is enough to rule out a default as a rational equilibrium. Under fixed rates, by contrast, the Central Bank would be less able or willing to act as a lender of last resort, unless, of course, the Central Bank has 50 billion pesos worth of foreign exchange, or an international line of credit of that amount.

For the same reason, a bank panic is much more likely in a fixed exchange rate regime. In the event of a banking panic, the Central Bank can act as a lender of last resort in a floating regime, but not under a pegged rate regime without jeopardizing the exchange rate peg itself. Wigmore (1987) has argued that the 
failure of the Fed to protect the U.S. banking system in the winter of 1932-3 was the result of the Fed's fears that lenderof-last-resort credits to the banks would undermine the link of the U.S. dollar to gold. In this way, the commitment to the gold standard opened the U.S. to a self-fulfilling banking panic. Similarly, in 1995, Argentina's strict currency board arrangements opened it to the threat of a banking crisis, since the Argentine Central Bank was unable to act as a lender of last resort.

What, then, are the appropriate circumstances for a pegged exchange rate regime for an emerging market. The first, and very rare, case is a true optimal currency union with one or more countries. In this case, a common central bank can act as lender of last resort for the whole union. Note that many cases of "permanent" exchange rate pegs, such as the CFA Franc in West Africa, or the dollar peg in Liberia, were not even remotely appropriate as optimal currency areas, and therefore produced situations of prolonged currency overvaluation.

A second exceptional case for pegging may be an extremely open and diversified economy with an extremely flexible labor market. Such an economy can adjust to external shocks through internal deflation if necessary, rather than depreciation. Also, by virtue of diversification, such an economy may be less likely to be hit by serious external shocks than an economy highly specialized in a few export goods, particularly natural resources. Hong Kong and Estonia, which both use currency boards, are possible examples. Even in these cases, however, there is still the need to maintain a lender of last resort mechanism. It is rarely recognized, but extremely pertinent, that Hong Kong has relied on the Bank of China to serve as a lender of last resort in the event of banking crises.

A third exceptional case for pegging, at least in a temporary manner, arises in the wake of hyperinflation or in the case of the introduction of a new national currency, as in the successor states of the Soviet Union and Yugoslavia. In both cases, the economy tends to be under-monetized, with extremely low ratios of $M$ to GDP. A temporary peg of the exchange rate serves several purposes: it increases confidence in a fragile currency; it stops a self-fulfilling flight from the new (or newly stabilized) currency; and most importantly, it provides an automatic mechanism for remonetization of the economy -- through the balance of payments. Thus, after Estonia pegged the Kroon to the deutschemark, Estonia ran a significant balance of payments surplus, as Estonia households and firms repatriated foreign exchange in order to build up money balances in the new currency. Foreign reserves and the money supply rose by more than 10 percent of GDP in the first two years. 
History has shown that the stabilization of a hyperinflation, and the introduction of a new currency, tend to be less costly in terms of lost output, with the use of a pegged rate rather than a floating rate (see Sachs, 1995, for further discussion of this point). The floating rate deprives the economy of the mechanism for automatic remonetization, and the currency also seems to suffer from a lack of confidence relative to a pegged rate. At the same time, however, it is very important to switch to from the pegged rate to a more flexible exchange rate arrangement (a float, crawling band, or some other flexible arrangement) as soon as the remonetization is substantially accomplished. If the pegged rate is maintained too long, then the economy is subjected to the problems noted earlier: inflexibility in the face of shocks (as in Mexico, 1994); and vulnerability to panics (as in Argentina, 1995, in the aftermath of the Mexican crisis). ${ }^{1}$

\section{The Central Bank should discourage the dollarization of accounts in the domestic banking system. Similarly, the government should avoid the dollarization of its own short-term debts.}

In many developing countries, particularly those recovering from high inflation, central banks often encourage reintermediation of the banking system by allowing dollar-indexed assets and liabilities. Even when these assets and liabilities are roughly balanced in overall totals (as is often required), there is usually maturity transformation, so that the dollar liabilities are short-term while the assets are longer-term. The main problem in this case is that the Central Bank is less able to act as a lender of last resort, even under floating exchange

\footnotetext{
It is at least arguable that Argentina presents a unique case. After 40 years of chronic high inflation, punctuated by episodes of hyperinflation, the economic team in 1991 judged that only the straightjacket of a currency board could break the historical cycle of monetary disarray and the virtual complete absence of credibility of stabilization policies. The currency-board arrangements have succeeded remarkably in reducing Argentina's inflation to low single-digit rates, indeed making Argentina one of the lowest inflation countries in the world. Moreover, economically policy has become directed to vitally needed "real" reforms: of labor markets, public administration, social security, tax policy, public ownership, and other areas.
}

Thus, the undoubted costs of Argentina's monetary straightjacket, including the banking panic of 1995 and Argentina's high labor costs in international terms, must be balanced against the historic break in its deeply disfunctional monetary policies over four decades. No other country failed for so long to find other institutional bases (e.g. central bank independence, pegged but adjustable exchange rates, etc.) to limit inflationary pressures. For that reason, few if any other countries should take Argentina's gamble on a strict currency board arrangement. The long-term consequences of Argentina's own bet on the currency board system are still to be seen. 
rates, since it must provide foreign exchange (dollars) in the event of a precipitous withdrawal of dollar balances. In many cases of dollar balances, therefore, dollar withdrawals are frozen when a bank run ensues; eventually, the dollar-denominated balances are then converted into domestic currency with some degree of confiscation.

Similar logic militates against the reliance of governments on short-term dollar denominated debts, such as the Mexican Government's issuance of tesobonos which played such havoc with Mexico in late 1994. Mexican Government indebtedness was not extraordinarily high in late 1994 (perhaps 35 percent of GDP), but it was dollar denominated and very short term. Since dollar debts were much higher than dollar foreign exchange reserves at the end of 1994, a market panic could and did develop. Investors in Mexican government debts refused to roll over the outstanding tesobonos and Mexico was pushed to the brink of default. Because the liabilities were dollar denominated, the Banco de Mexico was unable to stand behind the government's obligations via a line of domestic credit to the government. There was, contrarily, much less, if any, risk of default on the government's pesodenominated liabilities. (See Sachs, Tornell, and Velasco for further details on the Mexican case).

3. As a corollary to (1) and (2), currency board arrangements should be avoided, except in the case of very small, very open economies. Even then, the Central Bank should maintain some scope for lender-of-last resort actions, and should arrange international lines of credit in advance in order to be able to respond to a future banking crisis.

"Permanently" fixed exchange rates have almost always provoked a serious crisis -- whether in West Africa, Liberia, Panama, or more recently in Argentina (where the economy is now suffering from 20 percent unemployment, with no respite in sight). They are an invitation to chronic overvaluation, banking crises, and often both together. Moreover, despite the claims made by Hanke and Schuler, 1994, that currency board arrangements run smoothly despite the lack of a lender-of-last resort

facility, even Hong Kong has had to rely on the Bank of China, in conjunction with the Hong Kong and Shanghai Banking Corporation, to act as a lender of last resort in the event of the failure of Ka Wah Bank in 1995 (see Jao, 1992, p. 58 for details). And, of course, in 1995, Argentina required an emergency international loan package to help stave off an intense banking crisis (though see the discussion in footnote 2). 
4. The liberalization of controls on capital inflows should be managed gradually, to avoid a boom-bust cycle.

Many financial crises in the past 10 years were directly related to financial market liberalization, especially the elimination of controls on international financial movements. Crises linked to financial market liberalization include Argentina, Mexico, Venezuela in Latin America, and Israel, Sweden and Norway in Europe. Each case has important distinctive features, but all exhibited a boom-bust cycle, in which a sharp but temporary wave of capital inflow accompanied a pegged exchange rate. When the inflow subsided, the exchange rate needed to be devalued. The subsequent devaluation was often delayed until after a serious macroeconomic crisis had transpired.

The exact nature of the boom-bust cycle in capital inflows is hard to characterize precisely (Are these cycles rational? Are they based on myopic euphoria, which then bursts). In any case, the basic contours of the cycle are clear. Once capital controls are lifted, domestic banks and other financial intermediaries are able to tap the international capital markets. A sizeable stock of foreign debt is rapidly accumulated, until eventually the banks and other intermediaries hit a borrowing limit, determined by their capital base and institutional rules. When the limit is hit, the borrowing slows dramatically.

This repeated experience probably justifies the decisions of countries such as Chile and Korea to liberalize gradually, so that domestic financial institutions can not suddenly take on foreign debt. The borrowing limit is reached more gradually, so that the boom-bust cycle is greatly damped if not eliminated. The real exchange rate does not appreciate as much as in the case of rapid liberalization, and the subsequent devaluation needed after the slowdown in capital inflows is much less dramatic. A reasonable sequencing of the liberalization of capital inflows would probably allow immediately for free movements of foreign direct investment (including repatriation of capital and profits), followed in sequence by liberalization of portfolio equity investment, long-term borrowing by non-financial enterprises, short-term borrowing by non-financial enterprises, and then finally, by short-term commercial bank borrowing.

5. The BIS prudential standards for commercial banks are usually not sufficient for developing countries. More stringent capitalasset ratios should be encouraged, as well as rigorous minimum capital levels for banks.

Financial crises are stoked by undercapitalized banks, which are more vulnerable to self-fulfilling panics and more prone to excessively risky borrowing. (Raising the risk of the bank's 
portfolio effectively transfers wealth from the deposit insurance fund, usually provided by the government, to the bank's

shareholders). Most emerging markets lack effective institutions for bank supervision, so that the book value of bank capital often greatly overstates the amount of shareholder equity (e.g. bad loans may not be written down expeditiously). Moreover, the ownership structure of banks in emerging markets typically adds to their riskiness. Non-financial companies own the banks, which in turn lend to the companies that own them. Moreover, bank licenses are frequently issued on the basis of party politics, nepotism, or corruption. For all of these reasons, standard prescriptions for developed economies, such as a minimum capitalto-assets ratio of 8 percent, are likely to be grossly inadequate in the emerging markets context. ${ }^{2}$

\section{Responding to International Financial Crises}

Crisis prevention, alas, is only part of the story. Around 60 developing countries have experienced extreme financial crises in the past decade, in the form of debt defaults, debt reschedulings, or acute inflationary episodes. In the past two years, serious financial crises have hit Argentina, Latvia, Mexico, Turkey, and Venezuela, and lesser financial crises have hit many of the economies in transition. Dozens of developing country governments are still grappling with heavy burdens of foreign indebtedness, and new proposals are in the works for easing the burdens on the world's poorest countries of an overhang of multilateral debts.

The International Monetary Fund was set up in 1944 in part to serve as a kind of international lender of last resort (ILLR), especially in order to provide temporary financing to help member governments maintain pegged exchange rates during a period of internal adjustment. With the collapse of the pegged exchange rate regime in 1971, that specific function has diminished (if not quite disappeared), though the IMF still plays the role of central arbiter of developing country financial crises, with regard to advice, balance of payments lending, and coordinator of debt reduction operations.

In the past two years (Sachs, 1994, 1995) I have argued that the IMF's procedures lack an adequate conceptual and institutional basis, so that there is undue and costly inefficiency in the IMF's handling of international financial crises, and mainly of its role as the ILLR. These arguments have

${ }^{2}$ While it is far beyond the scope of this paper, I should note that in many developing countries a separate regulatory regime should be instituted for micro-finance institutions, which are specialized in providing small, uncollateralized loans to the poorest parts of the population (e.g. Grameen Bank in Bangladesh). 
recently been echoed in Eichengreen and Portes (1995), who concur with the need for revising the IMF's ILLR functions. It is analytically useful at this stage to examine the IMF's functions with respect to the three types of financial crises described in the previous section: fiscal crises; foreign exchange crises; and banking crises.

\section{Fiscal Crises}

In the past 15 years, dozens of developing country governments have experienced extreme financial embarrassment, ranging from acute illiquidity, leading to a temporary default on international obligations, to insolvency, requiring a permanent cancellation of some portion of the government's foreign debt obligations. (Notice that domestic obligations are rarely defaulted, since domestic-currency debts can be met through credits provided by the central bank, at the cost of indirect partial repudiation via inflation). An elaborate, if not wholly successful, institutional pattern has emerged to handle sovereign financial distress, including IMF loans, Paris Club relief on bilateral credits, and London Club relief on bank credits.

An efficient system for financial workouts would offer the following features. First, it would reduce moral hazards, by rewarding countries for maintaining their debt servicing and punishing countries adequately for managing their affairs in a manner which leads to default on debt obligations. Second, it would ensure the effective functioning of the debtor government at all stages of the financial workout, from the onset of the crisis to its final resolution. Third, it would create mechanisms for coordinating the actions of creditors, to achieve an efficient arrangement for renegotiating the financial terms on the problem debts.

Fifteen years of experience with the international debt crisis has demonstrated that current institutional arrangements do not meet these needs, even though the international system has evolved over time in a more efficient direction. As a recent IMF report (1995, p. 11) states, "Because there exists no welldefined and accepted legal process that is applicable in such cases, the process of debt resolution by involuntary restructuring is necessarily ad hoc with an uncertain outcome." The implications of the lack of a legal framework be appreciated by comparing the ad hoc international arrangements with the legal structure that governs financial workouts under the bankruptcy laws of the advanced economies. The U.S. Bankruptcy Code, chapter 9 (municipalities) and Chapter 11 (corporations), provides a particularly relevant contrast to the international arrangements, since the these chapters of the U.S. Bankruptcy Code are explicitly designed to handle cases of financial restructuring rather than liquidation. 
The U.S. Bankruptcy Code recognizes that efficient workouts require a regulatory environment at three stages of the workout. At the outset of insolvency (or at least the outset of creditor recognition of insolvency), the Code provides for a automatic standstill on debt servicing. Creditors are not allowed to pursue legal remedies to seize assets or to force the payment of debts. The law recognizes that each creditor, acting individually, has the incentive to enter a "grab race" for assets, to their mutual detriment. The automatic standstill prevents the premature liquidation or impairment of the insolvent entity, which would lower the overall value of the entity to the collective detriment of the creditors.

The second stage occurs between the onset of the stay and the exit from bankruptcy through reorganization. During this interim period, the insolvent entity (whether a municipality under Chapter 9 or a corporation under Chapter 11) will generally need access to new working capital. The overhang of prebankruptcy debt precludes a routine return to the capital markets, and high transactions costs among the current creditors normally precludes new lending from the existing creditors (since each creditor would like the others to make the emergency loans). The Bankruptcy Code solution is "debtor-in-possession (DIP) financing," through the assignment of priority to the repayment of the new, emergency loans ahead of the pre-bankruptcy claims. The bankruptcy court must approve the DIP financing, to ensure that the new loans actually enhance the value of the entity (thereby increasing the value of the pre-bankruptcy debts). Note importantly that, unlike the IMF, the bankruptcy court does not dispose of any money itself; the court's ability to deliver working capital lies in its power to assign priority to new market borrowing by the insolvent entity.

The third stage of the workout is the final balance sheet reorganization (debt reduction, debt service reduction, new loans, debt-to-equity swaps, etc.), usually combined with an operational reorganization (closure of loss-making units, divestiture, change in management, etc.). The key role of the bankruptcy law is to provide a negotiating framework which: (1) brings together all of the parties; (2) establishes mechanisms for cross-the-board settlements involving all classes of creditors; and (3) discourages free-riding or holdouts by individual creditors, and which pushes the process towards an expeditious resolution. The main tricks to avoid free-riding and holdouts are: non-unanimity among creditors in the confirmation of the reorganization plan; and the possibility of a court-led "cramdown" of a plan that is resisted by a particular group of creditors. A plan is confirmed if it is accepted by two-thirds or more of each creditor class by amount of claims, and by more than one half of each creditor class by the number of claimants. 
By these standards, the shortcomings in the international system are clear. There is no automatic standstill. An insolvent government typically faces legal harassment, or at least the threat of legal harassment, by individual creditors for months or years after the onset of the crisis. There are continued threats to seize airplanes, ships, and bank accounts, and to otherwise disrupt trade credit lines. The legal basis of these threats usually does not subside until the final confirmation of a Paris Club and London Club deal, and by that time, individual creditors may have done great damage to the debtor government's effectiveness.

There is essentially no debtor-in-possession financing, other than the IMF lending (and perhaps other official lending) itself. Thus, the only available funds for short-term working capital are typically in the form of internationally mobilized taxpayer dollars under IMF supervision. (Early in the debt crisis, the IMF orchestrated a few "involuntary lending" programs of the existing creditors, but these loans were very hard to arrange, and the IMF gave up by the mid-1980s. In the case of Mexico in 1995, for example, there was no active attempt to round up "involuntary" or voluntary private financing). The fact that working capital depends on taxpayer dollars has important political economy ramifications. The IMF is naturally extremely hesitant to lend "other people's money" into a highly visible crisis. Therefore, there are typically very long delays between the onset of insolvency and the start of IMF lending. During this period, the debtor government is starved for working capital, and often loses much of its capacity to govern. Russia during 1992 and 1993 is a vivid case of a government starved for working capital, thereby undermining the economic reform program (see Sachs, 1995, for details).

Finally, there are no effective rules to ensure an expeditious overall settlement that overcomes free-riding and holdouts. The Paris Club and London Club have evolved norms of behavior to keep the major creditors fairly united. Nonetheless, there are still sharp divisions among various creditor classes (bilaterals versus multilaterals versus commercial bank versus suppliers; large banks versus small banks) which incite strategic moves among the creditors, and which in extreme cases lead to individual holdouts that significantly delay a debt rescheduling or debt reduction operation. The process requires a large input of time and energy from the U.S. Treasury and other leading finance ministries. Large, high-profile countries (e.g. Poland, Mexico, Argentina) get more attention and more adequate remedies than smaller countries off of the world's political radar screen.

On the basis of earlier writings (Sachs 1994, 1995) I have been interpreted by others as recommending an "International Chapter 11," i.e. an international bankruptcy court. This is too 
literal an interpretation of my critique of current arrangements. I am recommending that we recognize and attempt to establish the functional equivalents of the key bankruptcy-code mechanisms: automatic standstills, priority lending, and comprehensive reorganization plans supported by non-unanimity rules. We do not need a literal bankruptcy court to move in the direction of such mechanisms. We could begin with a clear statement of IMF operating principles regarding each stage of the workout. We could search for ways to establish emergency priority lending from private capital markets, under IMF supervision. The IMF and governments could recommend model covenants for inclusion in future sovereign lending instruments that would allow for emergency priority lending and for efficient renegotiations of debt claims, should the future circumstances require.

\section{Foreign Exchange Crises}

There is rarely a role for IMF lending to support a particular nominal exchange rate of a member country. As the preceding analysis has stressed, pegged exchange rates are probably ineffective, and unsupportable, in most circumstances, especially in light of the high capital mobility now prevailing in the international economy. Of course, individual central banks may well have cause to intervene from time to time in their own currencies, but there is much less case for internationally coordinated interventions on behalf of a particular developing country.

There are, however, exceptions to this rule. International lending on behalf of a nominal exchange rate target makes sense when a government is attempting to establish confidence in a new national currency, or to reestablish confidence in an existing currency that has suffered a bout of extreme inflation. In both cases, money-to-GDP ratios tend to be very low, and there is the risk of a self-sustaining collapse of the currency, in which market panic induces a flight from the currency which in turn incites inflation and further currency flight. A descent into hyperinflation is at least a theoretical possibility, which become more likely the more tenuous is the use of the national currency in the domestic economy (as evidenced by extremely low ratios of money to income). Note that before the Plan Real, Brazil exhibited a ratio of high-powered money to GDP of less than one percent. Similarly, Kyrgyzstan's new currency, the Som, had an extremely tenuous role in the economy upon its introduction, with a ratio of M2 to GDP of around four percent in 1994 .

In these cases, there is a strong argument for an internationally provided stabilization fund, to help back the new currency, or newly stabilized currency, for the first year or two. The \$1 billion Polish Stabilization Fund in 1990 had a 
powerful impact in raising confidence in and political support for Poland's ambitious reform program. Estonia, fortunately, was able to create its own stabilization fund to support the new Kroon in 1992, using repatriated gold reserves that had been held by Sweden and the U.K. since World War II. Other countries, however, have not been so fortunate as to have the requisite reserves or to win the international support for a stabilization fund.

In most cases, the short-term pegging of the exchange rate should be viewed as a temporary stage until confidence in the currency is established and partial re-monetization of the economy proceeds. Therefore, a pegged rate might last for around one year, to be followed by a more flexible arrangement, such as a crawling band exchange rate system. The only realistic cases for a long-term pegged rate are in very small open economies, such as the Baltic states, which may viably choose a currency board arrangement.

\section{Banking Crises}

The basic international arrangement regarding banking crises is that central banks are responsible for the oversight and prudential regulation of their nation's banks, whether those banks are operating domestically or as subsidiaries in foreign countries. This division of labor may break down, however, when domestic banks have extensive short-term liabilities denominated in foreign currencies. In this case, the Central Bank may need substantial foreign exchange reserves to meet a sudden withdrawal of funds denominated in foreign exchange. Lacking adequate

foreign reserves, the domestic central bank may be unable to play the role of lender of last resort.

There is, at this point, no international regulatory regime governing the use of foreign-exchange denominated accounts in national banking systems. When Argentina's dollar-based banking system succumbed to crisis early in 1995, Argentina required an emergency international infusion of funds to stabilize the banking sector, since the Argentine Central Bank lacked the instruments and adequate reserves to play lender of last resort on its own. This was especially true as a result of the currency-board rules of the game which prevail in Argentina. Under the Argentine rules of the game, prevailing since April 1991, the Central Bank is enjoined from extending domestic credit, even to illiquid commercial banks. And even if the Central Bank were to violate its operating principals, the market's confidence in Argentina's exchange rate peg would be rapidly undermined. In the event, the Central Bank eased various reserve requirements, which amounted to a modest extension of credit to the banks. Reserves fell from some \$18 billion to \$14 billion in a couple of months. To staunch the continuing 
hemorrhage of deposits from the banking system, Argentina arranged an international package of official and private support for the banks, on the order of $\$ 10$ billion.

As described earlier, the most important way to reduce the frequency of this kind of crisis would be for governments and central banks to restrict the use of foreign currency deposits within a domestic banking system. At a minimum, the regulators should require that commercial banks' short-term foreign liabilities (deposits and CDS) should be matched by short-term and liquid foreign assets. Of course, in a world of derivatives, swaps, and other off-balance-sheet means of converting the currency denomination of assets and liabilities, regulators will occasionally be caught short, even if strong restrictions on open positions are in place.

In addition to regulatory changes such as these, there will be the need, from time to time, for emergency cross-border lending to support banking systems under siege as the result of the abrupt withdrawal of foreign-denominated funds. As in any lender-of-last-resort operation, the governing principle for emergency international support should be a combination of: ex ante prudential standards to avoid moral hazard; strong conditionality in the event of a bailout; timely lending to avert or to stem a panic; and closure (or merger) of insolvent, as opposed to illiquid, financial institutions. Probably the greatest shortcoming in proceeding with a general international system of support is the lack of adequate prudential supervision in most developing countries, and the lack of detailed attention at the level of the IMF and the BIS to the state of banking regulation in the developing countries. This suggests that it is a high priority for the BIS and IMF together to establish a far more rigorous system of monitoring of prudential arrangements (capital adequacy, reporting and disclosure, portfolio diversification, risk ratings, reserve provisioning, off-balancesheet monitoring and risk management, deposit insurance) of developing countries, as a prelude to enhanced international facilities for emergency lending operations to banking systems in distress. 
List of References

Calvo, G. (1995). "Varieties of Capital Market Crises," unpublished manuscript, University of Maryland, April.

Diamond, D. And P. Dybvig (1983). "Bank Runs, Deposit Insurance and Liquidity," Journal of Political Economy, June.

Eichengreen, B. and R. Portes (1995). Crisis? What Crisis? Orderly Workouts for Sovereign Debtors," London: Centre for Economic Policy Research.

Hanke, S. H., and K. Schuler (1994), "Currency Boards for Developing Countries," Sector Study Number 9, San Francisco: International Center for Economic Growth.

International Monetary Fund (1995). International Capital Markets: Developments, Prospects, and Policy Issues. Washington: International Monetary Fund, August.

Jao, Y.C. (1992). "Monetary system and banking structure," in H.C.Y. Ho and L.C. Chau (eds.), The Economic system of Hong Kong, Hong Kong: Asian Research Service, 1992.

Obstfeld, M. and K. Rogoff (1995), "The Mirage of Fixed Exchange Rates," NBER Working Paper No. 5191, July .

Sachs, J. (1994). "The IMF and Economies in Crisis," presented at London School of Economics, July 1994, forthcoming in LSE publication.

Sachs, J. (1995). "Do We Need a Lender of Last Resort," unpublished manuscript, Frank D. Graham Lecture, Princeton University, April.

Sachs, J., A. Tornell, and A. Velasco (1995). "Lessons from the Mexican Peso Crisis: What have we Learned?", HIID Discussion Paper, forthcoming in Economic Policy, 1996.

Wigmore, B. 1987. "Was the Banking Holiday of 1933 a run on the dollar rather than the banks?" Journal of Economic History, 47: $739-56$. 